\title{
Evaluation of Two Real-Time, TaqMan Reverse Transcription-PCR Assays for Detection of Rabies Virus in Circulating Variants from Argentina: Influence of Sequence Variation
}

\author{
Diego A. Caraballo ${ }^{1, *(D)}$, María A. Lombardo ${ }^{1}$, Paula Becker ${ }^{1}$, María S. Sabio ${ }^{2}$, Cristina Lema ${ }^{2}$, \\ Leila M. Martínez ${ }^{2}$, Fernando J. Beltrán ${ }^{1}, \mathrm{Yu} \mathrm{Li}^{3}$ and Daniel M. Cisterna ${ }^{2}$ (D) \\ 1 Instituto de Zoonosis "Luis Pasteur", Av. Díaz Vélez 4821, Ciudad Autónoma de Buenos Aires C1405DCD, \\ Argentina; mariale.lombardo@gmail.com (M.A.L.); paulabecker82@gmail.com (P.B.); \\ ferbelt@hotmail.com (F.J.B.) \\ 2 Servicio de Neurovirosis, Instituto Nacional de Enfermedades Infecciosas, Administración Nacional de \\ Laboratorios e Institutos de Salud (ANLIS), “Dr. Carlos G. Malbrán”, Av. Vélez Sarsfield 563, \\ Ciudad Autónoma de Buenos Aires C1282AFF, Argentina; ssoledad@anlis.gob.ar (M.S.S.); \\ clema@anlis.gob.ar (C.L.); lei.mmartinez@gmail.com (L.M.M.); dancis99@yahoo.com (D.M.C.) \\ 3 Poxvirus and Rabies Branch, Division of High Consequence Pathogens and Pathology, National Center for \\ Emerging and Zoonotic Infectious Diseases, Centers for Disease Control and Prevention, 1600 Clifton Road, \\ Atlanta, GA 30329, USA; yuli@cdc.gov \\ * Correspondence: diego7caraballo@gmail.com
}

Citation: Caraballo, D.A.; Lombardo, M.A.; Becker, P.; Sabio, M.S.; Lema, C.; Martínez, L.M.; Beltrán, F.J.; Li, Y.; Cisterna, D.M. Evaluation of Two Real-Time, TaqMan Reverse Transcription-PCR Assays for Detection of Rabies Virus in Circulating Variants from Argentina: Influence of Sequence Variation. Viruses 2021, 13, 23. https://dx.doi.org/10.3390/ v13010023

Academic Editor: Laurent Dacheux Received: 15 September 2020 Accepted: 17 November 2020 Published: 25 December 2020

Publisher's Note: MDPI stays neutral with regard to jurisdictional claims in published maps and institutional affiliations.

Copyright: () 2020 by the authors. Licensee MDPI, Basel, Switzerland. This article is an open access article distributed under the terms and conditions of the Creative Commons Attribution (CC BY) license (https: / / creativecommons.org / licenses/by/4.0/).

\begin{abstract}
In rabies diagnosis, it is essential to count on a rapid test to give a quick response. The combined sensitivity and robustness of the TaqMan RT-PCR assays (qRT-PCR) have made these methods a valuable alternative for rabies virus (RABV) detection. We conducted a study to compare the applicability of two widely used qRT-PCR assays targeting the nucleoprotein gene (LysGT1 assay) and leader sequences (LN34 qRT-PCR assay) of RABV genomes, in all variants circulating in Argentina. A total of 44 samples obtained from bats, dogs, cattle, and horses, that were previously tested for rabies by FAT and conventional RT-PCR, were used in the study. All variants were successfully detected by the pan-lyssavirus LN34 qRT-PCR assay. The LysGT1 assay failed to detect three bat-related variants. We further sequenced the region targeted by LysGT1 and demonstrated that the presence of three or more mismatches with respect to the primers and probe sequences precludes viral detection. We conclude that the LysGT1 assay is prone to yield variant-dependent false-negative test results, and in consequence, the LN34 assay would ensure more effective detection of RABV in Argentina.
\end{abstract}

Keywords: rabies virus; real time RT-PCR; nucleoprotein gene; phylogeny; diagnostic

\section{Introduction}

The rabies virus (RABV), the prototype of the Lyssavirus genus, family Rhabdoviridae, is the etiological agent of a fatal infection of the nervous system of mammals [1]. The genus has been initially divided into seven genotypes based on the nucleotide sequence of the nucleoprotein gene [2,3] and then confirmed by sequences of the glycoprotein [4] and the phosphoprotein [5] genes. Currently, according to the International Committee on Taxonomy of Viruses (ICTV), the genus Lyssavirus has been subdivided into 17 species, based on genetic distance, immunological features, and antigenic patterns in reactions with panels of antinucleocapsid monoclonal antibodies [1]. This classification is also supported by geographic distribution and host range. The availability of complete genome sequences made possible the identification of three distinct lyssavirus phylogroups: phylogroup I comprises RABV, Aravan lyssavirus (ARAV), Australian bat lyssavirus (ABLV), Bokeloh bat 
lyssavirus (BBLV), Duvenhage lyssavirus (DUVV), European bat 1 lyssavirus (EBLV-1), European bat 2 lyssavirus (EBLV-2), Gannoruwa bat lyssavirus (GBLV), Irkut lyssavirus (IRKV) and Khujand lyssavirus (KHUV); phylogroup II includes the Lagos bat lyssavirus (LBV), Mokola lyssavirus (MOKV) and Shimoni bat lyssavirus (SHIBV), and phylogroup III is represented by Ikoma lyssavirus (IKOV), Lleida bat lyssavirus (LLBV) and West Caucasian bat lyssavirus (WCBV) [4,6,7]. The rabies virus (RABV) is distributed worldwide, except for Japan, Ireland, Great Britain, New Zealand, Hawaii, Australia, Antarctica, and several Western European countries [4,8]. In the Americas, RABV is the only lyssavirus found [9]. Rabies virus circulates through two different epidemiological cycles: terrestrial and bat-borne, associated with different species within the orders Carnivora and Chiroptera, respectively. In Argentina, two terrestrial variants are found: V1 associated with domestic dogs; V2 circulates among sylvatic canids, particularly in the crab-eating fox, Cerdocyon thous [10,11]. Argentinian bat-borne variants can be subdivided into two groups: those circulating among insectivorous bats and variants associated with the hematophagous bat Desmodus rotundus. Five genus-specific distinct lineages were described in insectivorous bats associated with Tadarida, Myotis, Eptesicus, Histiotus, and Lasiurus-Dasypterus species from Argentina [12]. Although the prevalence of insectivorous bat-RABV is conspicuous, no human cases have yet been associated with these variants. The common vampire bat, Desmodus rotundus, is the main rabies sylvatic reservoir in Argentina, with high prevalence levels in northern provinces [13]. It is an enzootic disease in bovines from this region but also occurs in epizootic waves from distant territories, affecting thousands of cattle every year, and it was also responsible for two human deaths in 1997 and 2001 [14]. Two main groups of vampire bat-transmitted RABV have been recognized through phylogenetic analysis of the nucleoprotein gene sequence: V3 and V3A, distributed in the northeast (NEA) and the northwest (NWA) of Argentina, respectively [15].

Given the high lethality of rabies disease, in epidemiological surveillance, it is essential to count on a rapid diagnosis to give a quick response. The direct fluorescent antibody test (FAT) is the most frequently used method for the diagnosis of rabies, because of its high sensitivity and specificity [16,17]. During the past two decades, various conventional RT-PCR protocols were developed for the diagnostic amplification of RABV [16-18]. These assays proved to be both sensitive and specific tools for routine diagnosis, especially in decomposed samples $[19,20]$. Posteriorly, the introduction of fluorogenic probes enabled specific diagnosis by a hybridization reaction. Several Real Time RT-PCR (qRTPCR) protocols were developed using the TaqMan technology, which allows for rapid detection of RABV [16-18]. However, these probes and primers are often designed based on a limited number of sequences and thus may not represent the genetic diversity of all current variants. For example, single mutations for North American RABV strains in the region of the primers or the probe have been shown to alter the sensitivity of the qRT-PCR [21]. Thus, validation of probe-based assays in a diagnostics laboratory should be conducted to confirm the detection of all circulating variants in a specific region.

Molecular techniques (including TaqMan assays) have been considered as reference methods by the OIE for the post-mortem diagnosis of animal rabies [17]. A widely used TaqMan RT-qPCR assay, especially in European national reference laboratories [22] is based on the universal pan-lyssavirus primers JW12 and N165-146 and the LysGT1 TaqMan RABV probe developed by Wakeley et al. [23]. This oligo set spans a 111 nucleotide region including the transcription initiation signal and part of the coding sequence of the nucleoprotein $(\mathrm{N})$ gene. This set was designed for the specific detection of classical RABV and showed high levels of specificity and sensitivity [22-24]. More recently, the LN34 primers and probes set-another increasingly implemented assay-was designed and validated [25]. This assay amplifies a 165 nucleotide region including the leader sequence, the transcription initiation signal, and part of the coding sequence of the $\mathrm{N}$ gene, being partially overlapped with the locus targeted by the LysGT1 assay. The LN34 assay was validated using a panel containing representative members of major worldwide RABV variants and 13 other lyssaviruses, employing multiplex, degenerate primers. It incorporates a 
degenerate, locked nucleotide (LNA) modified probe, which confers higher oligo stability and increases sequence melting temperature $(\mathrm{Tm})$, allowing for the design of shorter probes which in turn are more effectively quenched and have a higher signal-to-noise ratio. Consequently, these are more sensitive probes, which provide robust target detection [26].

In this study, we test the applicability of these two widely used primers/probes sets in all variants circulating in Argentina, with special emphasis on vampire-bat transmitted RABV genetic variability. All variants were successfully detected using the LN34 assay, while the LysGT1 assay is prone to yield variant-dependent false-negative test results. Therefore, the LN34 assay would ensure more effective detection of RABV in Argentina.

\section{Materials and Methods}

\subsection{Samples}

A total of 44 samples obtained from bats, dogs, cattle, and horses that were previously tested for rabies by conventional RT-PCR and FAT, were analyzed by qRT-PCR LysGT1 and LN34 assays. All samples were received at the Instituto de Zoonosis Luis Pasteur in the period 2018-2020. The year of submission and place of origin are shown in Tables 1 and 2 and Figure 1. For FAT, Ammon's horns, brainstem, and cerebellum, or the whole brain, for dogs, cattle and horses, and bats, respectively, were used following the OIE protocols [17]. A 10\% tissue homogenate of the mentioned brain structures of each specimen was prepared in Minimum Essential Medium (MEM, Thermo Fisher Scientific, Waltham, MA, USA) following the World Health Organization (WHO) guidelines [27].

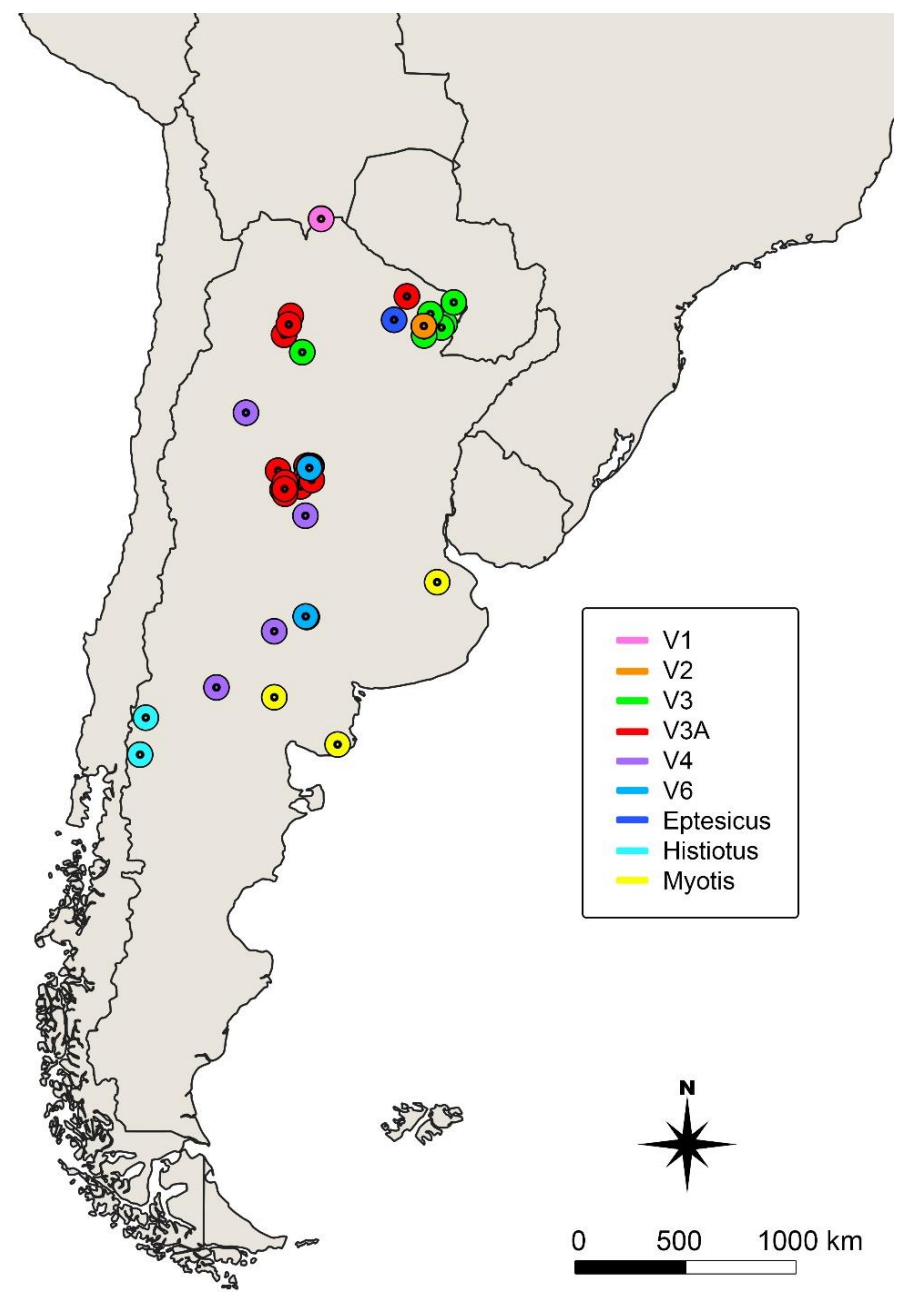

Figure 1. Map of Argentina, showing sampling localities. Colors indicate rabies virus (RABV) genetic variants. 


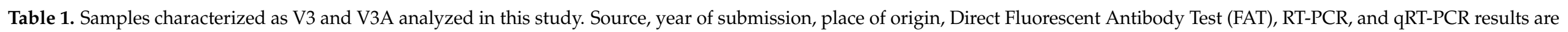
shown. The number of mismatches in the primers/probe region of the LysGT1 oligos is shown (right).

\begin{tabular}{|c|c|c|c|c|c|c|c|c|c|c|c|c|c|c|c|c|}
\hline \multirow[b]{2}{*}{$\begin{array}{c}\text { Sample } \\
\text { ID }\end{array}$} & \multirow[b]{2}{*}{ Year } & \multirow[b]{2}{*}{ Organism } & \multirow[b]{2}{*}{ Province } & \multirow[b]{2}{*}{ Locality } & \multirow[b]{2}{*}{ Latitude } & \multirow[b]{2}{*}{ Longitude } & \multirow[b]{2}{*}{ e FAT } & \multirow[b]{2}{*}{$\begin{array}{l}\text { RT- } \\
\text { PCR }\end{array}$} & \multicolumn{3}{|c|}{ qRT-PCR (Ct) } & \multicolumn{5}{|c|}{ Mismatches } \\
\hline & & & & & & & & & LN34 & LysGT1 & $\begin{array}{c}\beta- \\
\text { actin }\end{array}$ & Variant & JW12 & LysGT1 & $\begin{array}{l}\text { N165- } \\
146\end{array}$ & Total \\
\hline 1072 & 2018 & Horse & Córdoba & La Calera & -31.35 & -64.34 & Negative & Positive & 28 & - & 25 & V3A & & NS & & - \\
\hline 1073 & 2018 & Horse & Córdoba & La Calera & -31.35 & -64.34 & Negative & Positive & 29 & - & 24 & V3A & & NS & & - \\
\hline 1074 & 2018 & Vampire bat & Córdoba & $\begin{array}{l}\text { Unknown } \\
\text { (Colón)* }\end{array}$ & - & - & Negative & Positive & 18 & - & 25 & V3A & & NS & & - \\
\hline 1077 & 2018 & Horse & Córdoba & La Calera & -31.35 & -64.34 & Negative & Positive & 22 & - & 22 & V3A & & NS & & - \\
\hline 323 & 2019 & Bovine & Tucumán & Ticucho & -26.52 & -65.25 & Positive & Positive & 26 & - & 25 & V3A & 0 & 3 & 1 & 4 \\
\hline 801 & 2019 & Bovine & Córdoba & Santa María & -31.68 & -64.31 & Positive & Positive & 27 & - & 24 & V3A & 0 & 3 & 1 & 4 \\
\hline 840 & 2019 & Bovine & Salta & $\begin{array}{l}\text { Rosario de la } \\
\text { Frontera }\end{array}$ & -25.80 & -64.97 & Positive & Positive & 26 & - & 25 & V3A & 0 & 3 & 1 & 4 \\
\hline 916 & 2019 & Bovine & Córdoba & Calamuchita & -32.08 & -64.55 & Positive & Positive & 26 & - & 21 & V3A & 0 & 3 & 1 & 4 \\
\hline 973 & 2019 & Horse & Córdoba & Santa María & -31.72 & -64.18 & Positive & Positive & 37 & - & 25 & V3A & & NS & & - \\
\hline 975 & 2019 & Bovine & Córdoba & Santa María & -31.85 & -64.08 & Positive & Positive & 27 & - & 27 & V3A & 0 & 3 & 1 & 4 \\
\hline 1131 & 2019 & Bovine & San Luis & Junín & -32.20 & -65.32 & Positive & Positive & 24 & - & 22 & V3A & & NS & & - \\
\hline 1178 & 2019 & Bovine & Formosa & $\begin{array}{l}\text { Estanislao del } \\
\text { Campo }\end{array}$ & -25.06 & -60.08 & Positive & Positive & 20 & - & 25 & V3A & 0 & 3 & 1 & 4 \\
\hline 1322 & 2019 & Bovine & San Luis & $\begin{array}{l}\text { Santa Rosa de } \\
\text { Conlara }\end{array}$ & -32.35 & -65.21 & Positive & Positive & 27 & - & 25 & V3A & & NS & & - \\
\hline 1326 & 2019 & Bovine & Córdoba & La Patria & -31.52 & -65.50 & Positive & Positive & 32 & - & 26 & V3A & & NS & & - \\
\hline 1327 & 2019 & Bovine & Córdoba & Villa Dolores & -31.94 & -65.21 & Positive & Positive & 28 & - & 28 & V3A & 0 & 3 & 1 & 4 \\
\hline 1368 & 2019 & Bovine & Salta & La Candelaria & -26.13 & -65.05 & Positive & Positive & 28 & - & 26 & $\mathrm{~V} 3 \mathrm{~A}$ & 0 & 3 & 1 & 4 \\
\hline
\end{tabular}


Table 1. Cont.

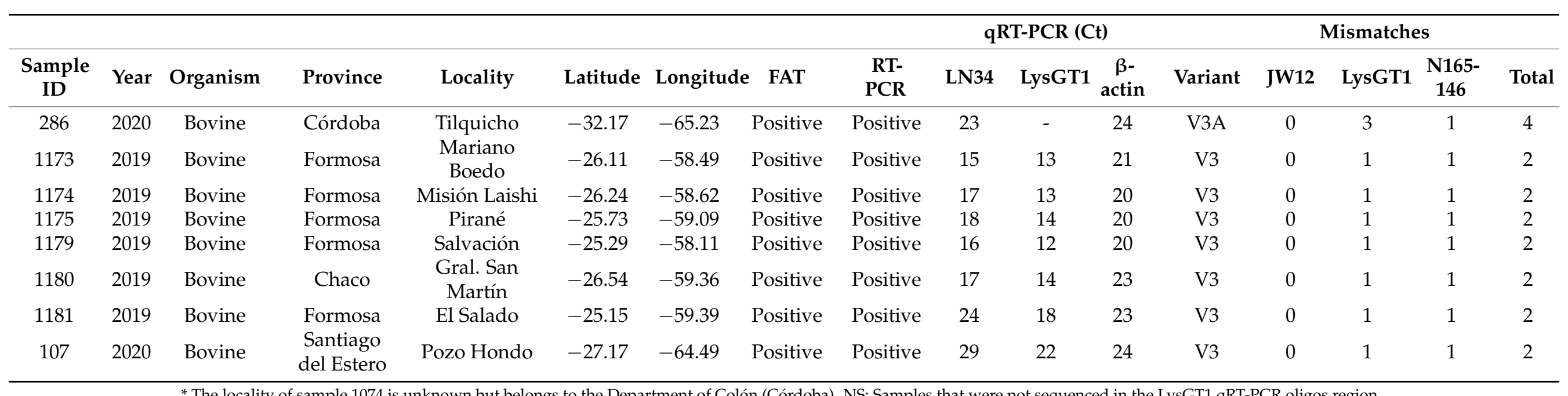

* The locality of sample 1074 is unknown but belongs to the Department of Colón (Córdoba). NS: Samples that were not sequenced in the LysGT1 qRT-PCR oligos region. 


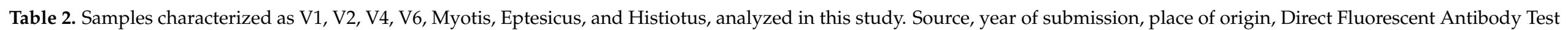

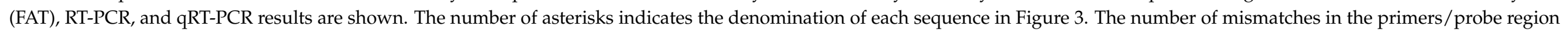
of the LysGT1 oligos is shown (right).

\begin{tabular}{|c|c|c|c|c|c|c|c|c|c|c|c|c|c|c|c|c|}
\hline \multirow[b]{2}{*}{$\begin{array}{c}\text { Sample } \\
\text { ID }\end{array}$} & \multirow[b]{2}{*}{ Year } & \multirow[b]{2}{*}{ Organism } & \multirow[b]{2}{*}{ Province } & \multirow[b]{2}{*}{ Locality } & \multirow[b]{2}{*}{ Latitude } & \multirow[b]{2}{*}{ Longitude } & \multirow[b]{2}{*}{ FAT } & \multirow[b]{2}{*}{$\begin{array}{l}\text { RT- } \\
\text { PCR }\end{array}$} & \multicolumn{3}{|c|}{ qRT-PCR (Ct) } & \multicolumn{5}{|c|}{ Mismatches } \\
\hline & & & & & & & & & LN34 & LysGT1 & $\beta$-actin & Variant & JW12 & LysGT1 & $\begin{array}{l}\text { N165- } \\
146\end{array}$ & Total \\
\hline 588 & 2018 & Dog & Salta & $\begin{array}{c}\text { Salvador } \\
\text { Mazza }\end{array}$ & -22.05 & -63.69 & Negative & Positive & 25 & 19 & 25 & V1 & 0 & 1 & 0 & 1 \\
\hline 713 & 2018 & Dog & Salta & $\begin{array}{c}\text { Salvador } \\
\text { Mazza }\end{array}$ & -22.05 & -63.69 & Positive & Positive & 26 & 22 & 21 & V1 & & NA & & - \\
\hline 848 & 2018 & Dog & Salta & $\begin{array}{c}\text { Salvador } \\
\text { Mazza }\end{array}$ & -22.07 & -63.69 & Positive & Positive & 22 & 18 & 23 & V1 & 0 & 1 & 0 & 1 \\
\hline 1182 & 2019 & Dog & Formosa & $\begin{array}{l}\text { Colonia } \\
\text { El } \\
\text { Bañadero }\end{array}$ & -26.19 & -59.36 & Positive & Positive & 22 & 20 & 23 & $\mathrm{~V} 2$ & & NA & & - \\
\hline 1183 & 2019 & Dog & Formosa & $\begin{array}{l}\text { Colonia } \\
\text { El } \\
\text { Bañadero }\end{array}$ & -26.18 & -59.37 & Positive & Positive & 22 & 20 & 29 & $\mathrm{~V} 2$ & 0 & 1 & 0 & 1 \\
\hline 1287 & 2018 & Bat & Neuquén & Neuquén & -38.97 & -68.10 & Positive & Positive & 21 & 21 & 18 & $\mathrm{~V} 4{ }^{*}$ & 0 & 0 & 2 & 2 \\
\hline 1291 & 2018 & Bat & Córdoba & $\begin{array}{c}\text { Río } \\
\text { Cuarto }\end{array}$ & -33.12 & -64.35 & Positive & Positive & 21 & 15 & 24 & $\mathrm{~V} 4^{* *}$ & 0 & 0 & 1 & 1 \\
\hline 1304 & 2018 & Bat & $\begin{array}{c}\text { La } \\
\text { Pampa }\end{array}$ & $\begin{array}{l}\text { Santa } \\
\text { Rosa }\end{array}$ & -37.10 & -65.67 & Positive & Positive & 19 & 14 & 21 & $\mathrm{~V} 4^{* *}$ & 0 & 0 & 1 & 1 \\
\hline 978 & 2019 & Bat & $\begin{array}{l}\text { La } \\
\text { Rioja }\end{array}$ & La Rioja & -29.41 & -66.85 & Positive & Positive & 22 & 19 & 22 & $\mathrm{~V} 4^{* *}$ & 0 & 0 & 1 & 1 \\
\hline 201 & 2018 & Bat & $\begin{array}{c}\text { La } \\
\text { Pampa }\end{array}$ & $\begin{array}{l}\text { Santa } \\
\text { Rosa }\end{array}$ & -36.60 & -64.34 & Negative & Positive & 25 & - & 21 & $\mathrm{~V} 6^{*}$ & 0 & 2 & 1 & 3 \\
\hline 974 & 2019 & Bat & Córdoba & $\begin{array}{l}\text { Córdoba } \\
\text { Capital }\end{array}$ & -31.42 & -64.19 & Positive & Positive & 27 & - & 24 & V6 $6^{* *}$ & 0 & 2 & 1 & 3 \\
\hline
\end{tabular}


Table 2. Cont.

\begin{tabular}{|c|c|c|c|c|c|c|c|c|c|c|c|c|c|c|c|c|}
\hline \multirow[b]{2}{*}{$\begin{array}{c}\text { Sample } \\
\text { ID }\end{array}$} & \multirow[b]{2}{*}{ Year } & \multirow[b]{2}{*}{ Organism } & \multirow[b]{2}{*}{ Province } & \multirow[b]{2}{*}{ Locality } & \multirow[b]{2}{*}{ Latitude } & \multirow[b]{2}{*}{ Longitude } & \multirow[b]{2}{*}{ FAT } & \multicolumn{5}{|c|}{ qRT-PCR (Ct) } & \multicolumn{3}{|c|}{ Mismatches } & \multirow[b]{2}{*}{ Total } \\
\hline & & & & & & & & $\begin{array}{l}\text { RT- } \\
\text { PCR }\end{array}$ & LN34 & LysGT1 & $\beta$-actin & Variant & JW12 & LysGT1 & $\begin{array}{c}\text { N165- } \\
146\end{array}$ & \\
\hline 442 & 2018 & Bat & $\begin{array}{c}\text { Buenos } \\
\text { Aires }\end{array}$ & $\begin{array}{c}\text { San } \\
\text { Miguel } \\
\text { del } \\
\text { Monte }\end{array}$ & -35.44 & -58.81 & Positive & Positive & 22 & - & 20 & Myotis * & 0 & 2 & 2 & 4 \\
\hline 622 & 2018 & Bat & $\begin{array}{c}\text { Río } \\
\text { Negro }\end{array}$ & Viedma & -40.81 & -63.00 & Positive & Positive & 21 & - & 22 & Myotis ** & 0 & 3 & 2 & 5 \\
\hline 29 & 2020 & Bat & $\begin{array}{c}\text { Río } \\
\text { Negro }\end{array}$ & $\begin{array}{c}\text { Choele } \\
\text { Choel } \\
\text { Junín de }\end{array}$ & -39.29 & -65.66 & Positive & Positive & 20 & - & 20 & Myotis ${ }^{* * *}$ & 0 & 3 & 2 & 5 \\
\hline 26 & 2020 & Bat & Neuquén & $\begin{array}{c}\text { los } \\
\text { Andes }\end{array}$ & -39.95 & -71.07 & Positive & Positive & 24 & 18 & 26 & Histiotus * & 0 & 0 & 1 & 1 \\
\hline 141 & 2020 & Bat & $\begin{array}{c}\text { Río } \\
\text { Negro }\end{array}$ & Bariloche & -41.13 & -71.31 & Positive & Positive & 22 & 17 & 19 & Histiotus ${ }^{* *}$ & 0 & 0 & 1 & 1 \\
\hline 175 & 2018 & Bat & $\begin{array}{c}\text { La } \\
\text { Pampa }\end{array}$ & $\begin{array}{l}\text { Santa } \\
\text { Rosa }\end{array}$ & -36.62 & -64.29 & Negative & Positive & 39 & - & 23 & Eptesicus & & NA & & - \\
\hline 1172 & 2019 & Bat & Chaco & Castelli & -25.95 & -60.62 & Positive & Positive & 24 & 19 & 23 & Eptesicus & 0 & 1 & 1 & 2 \\
\hline
\end{tabular}

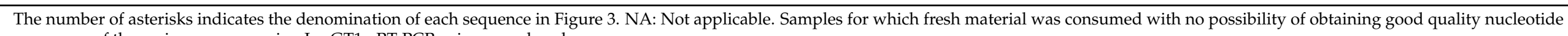
sequences of the region encompassing LysGT1 qRT-PCR primers and probe. 


\subsection{FAT}

Slides and controls were stained with an antinucleocapsid antibody (BIO-RAD, MarneLa-Coquette, France) according to the manufacturer's instructions.

\subsection{Viral RNA Extraction}

Viral nucleic acid extraction was performed using the High Pure Viral RNA kit (Roche Molecular Biochemicals, Mannheim, Germany) according to the manufacturers' instructions contained in the kit insert.

\subsection{RT-PCR and DNA Sequencing}

Reverse transcription and end-point PCR amplification were performed using primers 504 (Sense: 5' TATACTCGAATCATGATGAATGGAGGTCGACT 3') and 304 (Antisense: $5^{\prime}$ TTGACGAAGATCTTGCTCAT $3^{\prime}$ ) using the OneStep RT-PCR Kit (Qiagen, Venlo, The Netherlands) under conditions described by Orciari et al. [28]. Amplification products were checked by $2 \%$ agarose gel electrophoresis stained with ethidium bromide. A booster PCR was performed using the same primer pair. The product was quantified using agarose gel electrophoresis and sequenced using a BigDye Terminator v3.1 cycle sequencing kit according to the manufacturer's protocol using the ABI PRISM 310 Genetic Analyzer (Applied Biosystems Inc. Foster City, CA, USA).

\subsection{Phylogenetic Analysis}

A 191-bp region, obtained with primers 504 and 304 was analyzed (Supplementary Figure S1). In addition to the samples that were subjected to qRT-PCR and sequenced, we sequenced 11 samples typed as V3 (6 samples) and V3A (5 samples) by Torres et al. [15]. We included 32 additional reference sequences corresponding to all RABV variants circulating in Argentina, retrieved from Genbank. Nucleotide alignments were performed with Clustal Omega [29].

The phylogenetic analysis was performed in MrBayes 3.2.7a [30] on the CIPRES Science Gateway [31]. Nucleotide substitution models were estimated using MrModeltest [32] under the Akaike Information Criterion (correcting by the number of taxa). The selected substitution model was K80.

We ran Markov chain Monte Carlo (MCMC) analyses for two independent runs for $5 \times 10^{7}$ generations, sampling every $5 \times 10^{3}$. Convergence was assessed by analyzing the potential scale reduction factor (PSRF) and the average standard deviation of split frequencies (ASDSF). The "burnin" phase was set up in the generation which fulfilled PSRF values of 1.00-1.02 for all estimated parameters and standard deviations lower than 0.01 , which corresponded to $9.49 \%$ of the total run. Trees were visualized with iTOL [33] and Figtree [34].

\subsection{LysGT1/ß-Actin $q R T-P C R$}

The LysGT1 qRT-PCR was performed in a duplex reaction with the $\beta$-actin gene, following Wakeley et al. [23], except for the following modifications. Duplex qRT-PCR was performed using a total volume of $20 \mu \mathrm{L}$ on $5 \mu \mathrm{l}$ of extracted RNA and $15 \mu \mathrm{l}$ of the master mix components from the SensiFAST ${ }^{\mathrm{TM}}$ Probe No-ROX One-Step Kit (Bioline, London, UK), following manufacturer's instructions. The LysGT1/ $\beta$-actin qRT-PCR was performed on an Applied Biosystems 7500 Real-Time PCR System (Applied Biosystems, Foster City, CA, USA). The following thermal cycling conditions were used: $48^{\circ} \mathrm{C}$ for $15 \mathrm{~min}(\mathrm{RT}), 95^{\circ} \mathrm{C}$ for $10 \mathrm{~min}$ (inactivation), followed by 45 cycles of $95^{\circ} \mathrm{C}$ for $30 \mathrm{~s}, 52^{\circ} \mathrm{C}$ for $30 \mathrm{~s}$, and $72{ }^{\circ} \mathrm{C}$ for $20 \mathrm{~s}$. Critical threshold cycle numbers $(\mathrm{Ct})$ were determined automatically with the Applied 7500 Real-Time PCR System (Applied Biosystems, Foster City, CA, USA). Negative (FAT and RT-PCR negative samples) and positive controls (CVS RNA) were included in each assay for its validation. 


\subsection{LN34 qRT-PCR}

The LN34 assay was carried out following Wadhwa et al. [25]. Samples were assayed in a $25-\mu \mathrm{L}$ reaction mixture containing $2 \mu \mathrm{L}$ of RNA, with the AgPath-ID ${ }^{\mathrm{TM}}$ One-Step RT-PCR kit (Life Technologies, Carlsbad, CA, USA). The cycling conditions were as follows: reverse transcription at $50{ }^{\circ} \mathrm{C}$ for $30 \mathrm{~min}$, followed by RT inactivation/initial denaturation at $95^{\circ} \mathrm{C}$ for $10 \mathrm{~min}$, and amplification for 45 cycles at $95^{\circ} \mathrm{C}$ for $15 \mathrm{~s}$ and $56^{\circ} \mathrm{C}$ for $30 \mathrm{~s}$ on an Applied Biosystems 7500 Real-Time PCR System (Applied Biosystems, Foster City, CA, USA). Corresponding controls were run in each assay. A sample was considered positive if the LN34 Ct $\leq 35$.

\subsection{LysGT1 qRT-PCR Amplicon Sequencing and Alignment}

A $111 \mathrm{bp}$ region of the nucleoprotein gene comprising the amplicon used in qRT-PCR was sequenced in 32 samples covering all variants circulating in Argentina, performing RT$\mathrm{PCR}$ and a subsequent sequencing protocol using primers $001-921 \mathrm{~B}$ and $550 \mathrm{~F}$ as described previously [15]. Sequences were deposited in Genbank (Accession Numbers: MW302176MW302207). The 32 sequences were aligned with a reference RABV genome isolated from Desmodus rotundus (Genbank Accession Number: KU523255). Real Time RT-PCR primers JW12 and N165-146 as well as the probe LysGT1 were mapped in the resulting alignment. Supplementary Figure S1 shows a schematic representation of the probes and the four total primer pairs used in this study.

\section{Results}

A total of 44 samples corresponding to bats, dogs, cattle, and horses, with a positive diagnosis by conventional RT-PCR and/or FAT, were tested by qRT-PCR using LN34 and LysGT1 assays. All variants were successfully detected using the LN34 primers and probe set. In contrast, the LysGT1 assay positively detected variants V1, V2, V3, V4, Eptesicus, and Histiotus but failed to detect variants V3A, V6, and Myotis (Tables 1 and 2). Notably, there was a relatively high level of discrepancy between FAT and RT-PCR: 7 samples out of 44 were negative by FAT while positive by RT-PCR (Tables 1 and 2).

The molecular typing based on $191 \mathrm{bp}$ involving the $3^{\prime}$ terminus of the $\mathrm{N}$ gene and 51 downstream nucleotides was unequivocal. The final matrix contained 87 sequences (Supplementary File S1). No internal gaps or stop codons were detected in the alignment. The Bayesian phylogeny recovered the expected relationships among variants circulating in Argentina (Figure 2). Namely, the two epidemiological cycles (terrestrial and batborne) were reciprocally monophyletic, as well as each particular variant within them, confirming that the employed primer set produces informative sequences for phylogenetic genotyping. Both vampire bat-transmitted subgroups, V3 and V3A, were also reciprocally monophyletic, showing that they constitute well-differentiated RABV lineages.

The 19 samples typed as V3A (Figure 2) were negative by the LysGT1 assay (Table 1). In contrast, the seven samples typed as V3 were positive by this assay (Figure 2, Table 1). The region comprising both primers is invariant among V3 and V3A (Figure 3); consequently, the difference in RABV detection by qRT-PCR lies in the number of mismatches in the probe region. Variant V3 has a G instead of A in the base number 17 of the LysGT1 probe sequence. This substitution is also present in $\mathrm{V} 3 \mathrm{~A}$, which has two additional mismatches: a $\mathrm{G}$ (instead of $\mathrm{A}$ ) in base 11 and a $\mathrm{C}$ (instead of T) in base 23, in all sequences (Figure 3).

As mentioned, all V3 and V3A samples yielded detectable products in the LN34 assay, although sample 973 (V3A) had a Ct $>35$ which should be considered inconclusive and repeated according to the current LN34 protocol [35]. Indeed, we repeated three times the RNA extraction and subsequent qPCR protocol and obtained Ct values between 37 and 38 . Notably, the $\beta$-actin Cts were repeatedly near 25 , and it is undoubtedly a positive sample since we obtained FAT and RT-PCR positive results (Table 1), and we further successfully sequenced the $249 \mathrm{bp}$ amplicon enabling variant determination (Figure 2). We interpret that a $\mathrm{Ct}$ value of 37, although inconclusive per se, falls within the limit of detection of the LN34 assay. 
Twelve out of 18 samples typed as terrestrial and non-vampire-bat variants were positive by the LysGT1 assay (Figure 2, Table 2). Terrestrial variants V1 and V2 were detected in all cases and depict only one mismatch with respect to the probe sequence (Figure 3, Table 2). The most frequent variant circulating in Argentina is V4 which belongs to the widespread bat Tadarida brasiliensis. This variant was successfully amplified and detected by qRT-PCR in the four individuals analyzed, one of them showing two mismatches in the region comprising primer N165-146, while the remaining having one mismatch (Figure 3, Table 2). The variant circulating among bats of the genus Histiotus was also positively diagnosed by this method, both samples depicting 1 mismatch in the region of primer N165-146. In contrast, the variant circulating in Lasiurus and Dasypterus (V6) was negatively diagnosed. The two samples showed three mismatches: two in the probe region and one in the primer N165-146. The three Myotis samples were also undetected and depicted the highest levels of variation in the region delimited by primers JW12 and N165-146, showing two and three mismatches in the probe region and two mismatches in the region corresponding to primer N165-146. One of the two samples typed as Eptesicus was positive by qRT-PCR, while the other did not produce detectable amplification by this method. We could only obtain a good quality sequence of the region encompassing the qRT-PCR oligos in the positively diagnosed sample, which showed two total mismatches, one in the probe region and one with respect to primer N165-146.
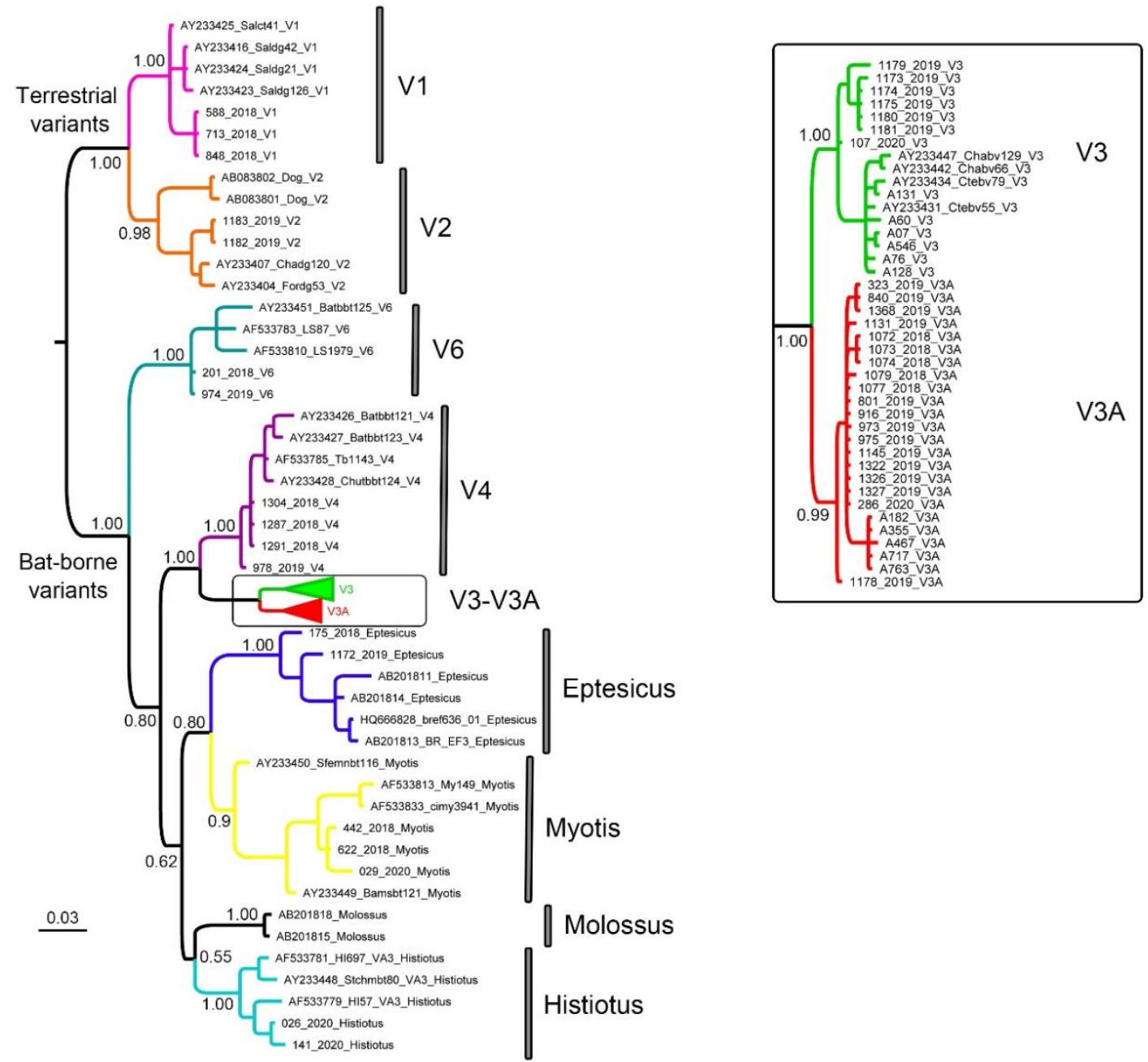

Figure 2. Bayesian phylogeny of 87 sequences based on 191 bp involving the $3^{\prime}$ terminus of the RABV N gene and 51 downstream nucleotides. Bayesian posterior probability of main clades is shown, as well as the scale (substitutions/site). In the left panel, the subclade (V3, V3A) is expanded. 
All terrestrial and non-vampire-bat variants were detected by the LN34 assay and considered positive $(\mathrm{Ct} \leq 35)$ according to the current protocol [35]. The only exception was sample 175, typed as Eptesicus, which yielded a Ct of 39 (Table 2). We repeated three times the RNA extraction and obtained $\mathrm{Ct}$ values of 39. Again, the $\beta$-actin $\mathrm{Ct}$ values were low (between 23 and 24). Although it is undoubtedly a positive sample since we obtained RT-PCR positive results (Table 1) and sequenced the $249 \mathrm{bp}$ amplicon (Figure 2), it was negative by FAT and, as mentioned, by the LysGT1 assay. As occurred with sample 973 (V3A), we interpret that a $\mathrm{Ct} \leq 35$, although inconclusive, is (weakly) detectable by the LN34 assay.

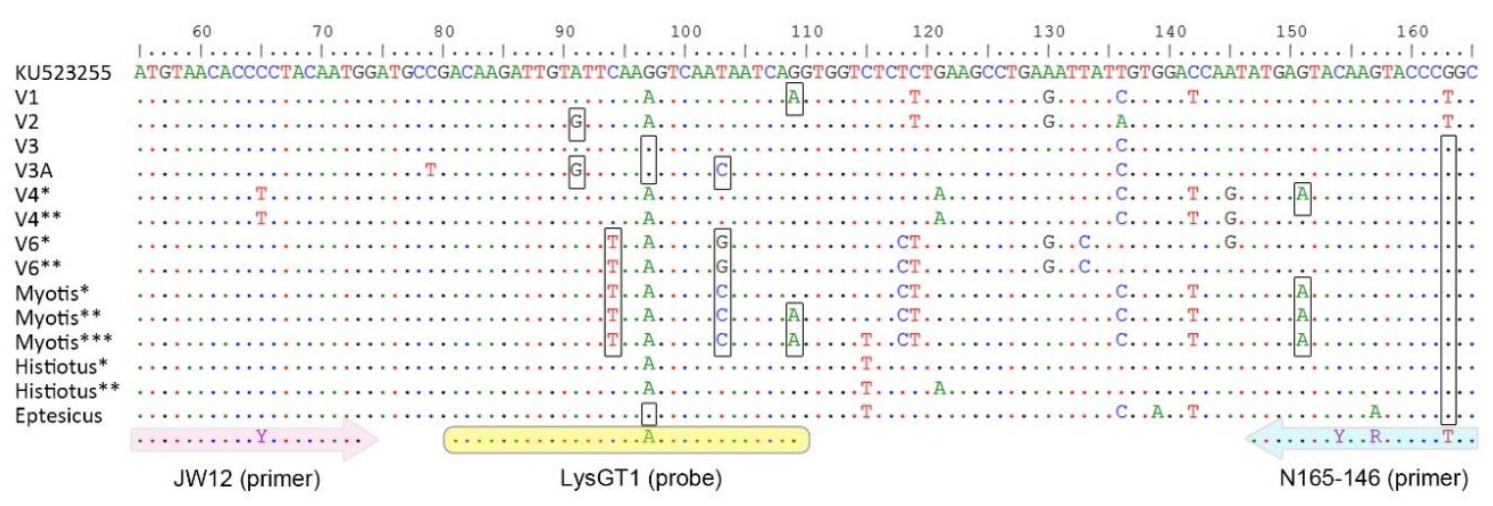

Figure 3. Alignment showing variability of Argentinian RABV genetic variants in the region comprising the amplicon used in the LysGT1 qRT-PCR assay. Primers JW12 and N165-146 and the probe LysGT1 were mapped in the resulting alignment. Dots depict conserved nucleotides. Mismatches of the primers and probe are indicated with black empty boxes. The sequence used as reference is a variant isolated from Desmodus rotundus (Genbank Accession Number: KU523255). The number of asterisks after variant denomination corresponds to different samples (Table 2). The remaining RABV variants depict no variation across samples in the region shown.

\section{Discussion}

The World Organization for Animal Health (OIE) recommends testing diagnostic assay performance for virus variants circulating in a certain working area [16]. In Argentina, there are at least nine different RABV genetic lineages. Two variants are restricted to canids, five of them are found in specific insectivorous bat genera and two related variants circulate among vampire bats. Validation of a RABV qRT-PCR protocol in Argentina should accomplish the correct amplification of all circulating variants, especially those with a higher incidence in public health.

Crucial for this survey was the unequivocal RABV variant identification. Previous studies have shown that complete [15] or partial $[10,12] \mathrm{N}$ gene sequences successfully discriminated variants circulating in Argentina. However, partial sequence analyses were obtained from amplicons using primers $10 \mathrm{~g}$ and 304, which are $1449 \mathrm{bp}$ long [36]. In this study, we show that the combination of primers 504 and 304 is capable of separating all circulant RABV variants from Argentina (Figure 2). This is an important advantage for laboratories involved in epidemiological surveillance since this primer set produces a short amplicon ( $249 \mathrm{bp})$, which has been shown to be more sensitive especially in decomposed samples [20], which would account for the relatively high discrepancies (16\%) between FAT and RT-PCR results (Tables 1 and 2).

In this study, we compared the effectiveness of two widely used sets of qRT-PCR primers and probes spanning partially overlapping regions of the nucleoprotein gene for the detection of classical rabies virus, in all variants circulating in Argentina. Both assays, LysGT1 and LN34, were designed based on a high number of lyssavirus variants, although the former was specifically designed for RABV detection, while the latter is a pan-lyssavirus assay $[23,25]$. Both assays have shown comparable detection limits: 16.7-25.8 copies/ $\mu$ L for LysGT1 [22] and eight copies (95\% confidence interval: 0-18 copies) 
for LN34 [26]. Hence both were expected to positively detect RABV variants circulating in Argentina.

The LysGT1 assay proved to be successful in RABV detection of terrestrial V1 and V2, as well as insectivorous-related variants V4 and Histiotus, all of which depict less than two total mismatches with respect to the region encompassing both primers (JW12 and N165-146) and the probe (LysGT1) (Figure 3, Table 2). However, it failed in the positive detection of RABV variants of insectivorous bats of the genera Myotis and Lasiurus-Dasypterus (Figure 3, Table 2). A simple rule can be established to predict the performance of the qRTPCR carried out with the LysGT1 assay: a maximum of two total mismatches with respect to the primers and probe sequences allows RABV detection, while the presence of three or more total mismatches precludes viral detection with no exception. Given that mismatches in the probe sequences have more impact on both sensitivity and specificity of TaqMan qRT-PCR than mismatches in primer sequences [37,38], another nonexclusive rule could be established if only the probe is taken into consideration: a maximum of one mismatch allows viral detection, while two or more substitutions hinder positive diagnosis. Both rules apply for all variants, independent of their origin (terrestrial, insectivorous bat-related, or vampire bat-related variants). The only variant for which we obtained contrasting results was Eptesicus (Table 2). It is an infrequent variant and we could only include two samples, one of which was positively detected and fits the above-mentioned rule, since it shows a mismatch in the probe region and another in primer N165-146, totalizing two mismatches. We speculate that the other sample had at least an extra mismatch, but we could not obtain a good quality sequence of this region.

As mentioned above, in Argentina, vampire transmitted-RABV produces thousands of deaths in cattle yearly and has caused two human deaths in the past 25 years [14]. Although infecting the same host species, V3 and V3A have been shown to be genetically distinct in analyses based on the nucleoprotein gene $(\mathrm{N})$ nucleotide sequences [12], this study. Indeed, these two variants differ in the region encompassing the probe LysGT1, which is determinant for the performance of this qRT-PCR assay.

All variants were successfully detected using the LN34 assay, making it the preferable alternative compared with LysGT1. The only two samples that were inconclusive according to the developers' protocol [35] yielded detectable products but with high $(\leq 35)$, but reproducible, Ct values. The LN34 assay was validated in a multisite study involving 14 laboratories, testing almost 3000 samples from the Americas, Africa, Asia, Europe, and the Middle East [26]. This assay showed the capability of detecting fresh tissue samples but also frozen, deteriorated, and even formalin-fixed brain tissue. The LN34 depicted high specificity $(99.68 \%)$ and sensitivity $(99.90 \%)$ compared with the FAT test and enabled the identification of both FAT false-positive and false-negative results [26]. As occurs with the LysGT1 assay in the present study, the LN34 assay has a tolerance of a maximum of 1 mismatch in the probe sequences [26]. In a recent study based on formalin-fixed human brain tissue, the LN34 assay proved to be more sensitive than traditional PCR, probably due to the use of a shorter amplicon [39]. Furthermore, direct sequencing of the $165 \mathrm{bp}$ LN34 amplicon allowed rapid and low-cost sample genetic typing. Taking into account the above-mentioned evidence, and in addition to the results presented in this study, the LN34 assay can be considered a reliable and robust method for rabies diagnostics and typing of variants circulating in Argentina and, at least, in the Southern Cone of South America.

\section{Conclusions}

In the present study, we showed the extent and limits of two TaqMan qRT-PCR assays for RABV diagnosis in Argentina. We conclude that the LysGT1 assay is prone to yield variant-dependent false-negative test results, and in consequence, the use of LN34 assay in diagnostic laboratories would ensure more effective detection of circulating RABV variants in Argentina.

Supplementary Materials: The following are available online at https:/ / www.mdpi.com/1999-491 5/13/1/23/s1, Supplementary File S1: Nucleotide alignment of 87 RABV sequences of 140 bp of the 
N gene and 51 bp downstream, Supplementary Figure S1: Schematic representation of primer sets and probes used in this study.

Author Contributions: Conceptualization, D.A.C., M.A.L., P.B., F.J.B., Y.L., and D.M.C.; Methodology, D.A.C., M.A.L., P.B., M.S.S., C.L., L.M.M., and D.M.C.; Formal analysis, D.A.C.; Investigation, D.A.C. and D.M.C.; Resources, F.J.B. and D.M.C.; Writing-original draft preparation, D.A.C., M.A.L., and D.M.C.; Writing—review and editing, D.A.C., M.A.L., F.J.B., Y.L., and D.M.C.; Visualization, D.A.C., P.B., Project administration, D.A.C., F.J.B. and D.M.C.; Funding acquisition, F.J.B. and D.M.C. The findings and conclusions in this report are those of the authors and do not necessarily represent the official position of the Centers for Disease Control and Prevention. All authors have read and agreed to the published version of the manuscript.

Funding: This research was funded by the Instituto de Zoonosis Luis Pasteur (Buenos Aires, Argentina) and the Instituto Nacional de Enfermedades Infecciosas, Administración Nacional de Laboratorios e Institutos de Salud (ANLIS) “Dr. Carlos G. Malbrán” (Argentina).

Institutional Review Board Statement: This study was approved by the Ethics and Research Committee of the Instituto de Zoonosis Luis Pasteur.

Informed Consent Statement: Not applicable.

Data Availability Statement: Data is available in the article and supplementary material.

Acknowledgments: The authors would like to thank Gabriel L. Cicuttin and M. Nazarena de Salvo for suggestions on the manuscript. D.A.C. would like to thank Juan B. Beaudoin for his inspiration and orientation and Sabrina L. López for her kind and constant support.

Conflicts of Interest: The authors declare no conflict of interest. The funders had no role in the design of the study; in the collection, analyses, or interpretation of data; in the writing of the manuscript, or in the decision to publish the results.

\section{References}

1. Walker, P.J.; Siddell, S.G.; Lefkowitz, E.J.; Mushegian, A.R.; Dempsey, D.M.; Dutilh, B.E.; Harrach, B.; Harrison, R.L.; Hendrickson, R.C.; Junglen, S.; et al. Changes to virus taxonomy and the International Code of Virus Classification and Nomenclature ratified by the International Committee on Taxonomy of Viruses (2019). Arch. Virol. 2019, 164, 2417-2429. [CrossRef] [PubMed]

2. Bourhy, H.; Kissi, B.; Tordo, N. Molecular diversity of the lyssavirus genus. Virology 1993, 194, 70-81. [CrossRef] [PubMed]

3. Bourhy, H.; Kissi, B.; Lafon, M.; Sacramento, D.; Tordo, N. Antigenic and molecular characterization of bat rabies virus in Europe. J. Clin. Microbiol. 1992, 30, 2419-2426. [CrossRef]

4. Badrane, H.; Bahloul, C.; Perrin, P.; Tordo, N. Evidence of two lyssavirus phylogroups with distinct pathogenicity and immunogenicity. J. Virol. 2001, 75, 3268-3276. [CrossRef]

5. Nadin-Davis, S.; Abdel-Malik, M.; Armstrong, J.; Wandeler, A. Lyssavirus P Gene characterisation provides insights into the phylogeny of the genus and identifies structural similarities and diversity within the encoded phosphoprotein. Virology 2002, 298, 286-305. [CrossRef]

6. Fooks, A. The challenge of new and emerging lyssaviruses. Expert Rev. Vaccines 2004, 3, 333-336. [CrossRef]

7. Gunawardena, P.S.; Marston, D.A.; Ellis, R.J.; Wise, E.L.; Karawita, A.C.; Breed, A.C.; McElhinney, L.M.; Johnson, N.; Banyard, A.C.; Fooks, A.A. Lyssavirus in Indian flying foxes, Sri Lanka. Emerg. Infect. Dis. 2016, 22, 1456-1459. [CrossRef]

8. Kwan, N.C.; Ogawa, H.; Yamada, A.; Sugiura, K. Quantitative risk assessment of the introduction of rabies into Japan through the illegal landing of dogs from Russian fishing boats in the ports of Hokkaido, Japan. Prev. Veter-Med. 2016, 128, 112-123. [CrossRef]

9. Rupprecht, C.; Kuzmin, I.; Meslin, F. Lyssaviruses and rabies: Current conundrums, concerns, contradictions and controversies. F1000Research 2017, 6, 184. [CrossRef]

10. Cisterna, D.M.; Bonaventura, R.; Caillou, S.; Pozo, O.; Andreau, M.L.; Fontana, L.D.; Echegoyen, C.; De Mattos, C.; De Mattos, C.; Russo, S.; et al. Antigenic and molecular characterization of rabies virus in Argentina. Virus Res. 2005, 109, 139-147. [CrossRef]

11. Amarilla, A.C.F.; Pompei, J.C.A.; Araujo, D.B.; Vázquez, F.A.; Galeano, R.R.; Delgado, L.M.; Bogado, G.; Colman, M.; Sanabria, L.; Iamamoto, K.; et al. Re-emergence of rabies virus maintained by canid populations in Paraguay. Zoonoses Public Health 2017, 65, 222-226. [CrossRef] [PubMed]

12. Piñero, C.; Dohmen, F.G.; Beltran, F.; Martinez, L.; Novaro, L.; Russo, S.; Palacios, G.; Cisterna, D.M. High diversity of rabies viruses associated with insectivorous bats in Argentina: Presence of several independent enzootics. PLoS Negl. Trop. Dis. 2012, 6, e1635. [CrossRef] [PubMed]

13. Delpietro, H.A.; Russo, R.G. Ecological and epidemiologic aspects of the attacks by vampire bats and paralytic rabies in Argentina and analysis of the proposals carried out for their control. Rev. Sci. Tech. OIE 1996, 15, 971-984. [CrossRef]

14. Delpietro, H.A.; Gury-Dhomen, F.; Larghi, O.P.; Mena-Segura, C.; Abramo, L. Monoclonal antibody characterization of rabies virus strains isolated in the river plate basin. J. Veter-Med. Ser. B 1997, 44, 477-483. [CrossRef] [PubMed] 
15. Torres, C.; Lema, C.; Dohmen, F.G.; Beltrán, F.; Novaro, L.; Russo, S.; Freire, M.C.; Velasco-Villa, A.; Mbayed, V.A.; Cisterna, D.M. Phylodynamics of vampire bat-transmitted rabies in Argentina. Mol. Ecol. 2014, 23, 2340-2352. [CrossRef] [PubMed]

16. World Health Organization. WHO Expert Consultation on Rabies: Third Report; World Health Organization: Geneva, Switzerland, 2018; ISBN 9789241210218.

17. World Organization for Animal Health (OIE). Rabies (infection with rabies virus and other lyssaviruses). In Manual of Diagnostic Tests and Vaccines for Terrestrial Animals 2019; World Organisation for Animal Health: Paris, France, 2018; pp. 578-612.

18. Fooks, A.R.; Johnson, N.; Freuling, C.M.; Wakeley, P.R.; Banyard, A.C.; McElhinney, L.M.; Müller, T. Emerging technologies for the detection of rabies virus: Challenges and hopes in the 21st century. PLoS Negl. Trop. Dis. 2009, 3. [CrossRef]

19. David, D.; Yakobson, B.; Rotenberg, D.; Dveres, N.; Davidson, I.; Stram, Y. Rabies virus detection by RT-PCR in decomposed naturally infected brains. Vet. Microbiol. 2002, 87, 111-118. [CrossRef]

20. Beltran, F.J.; Dohmen, F.G.; Del Pietro, H.; Cisterna, D.M. Diagnosis and molecular typing of rabies virus in samples stored in inadequate conditions. J. Infect. Dev. Ctries. 2014, 8, 1016-1021. [CrossRef]

21. Hughes, G.J.; Smith, J.S.; Hanlon, C.A.; Rupprecht, C.E. Evaluation of a TaqMan PCR assay to detect rabies virus RNA: Influence of sequence variation and application to quantification of viral loads. J. Clin. Microbiol. 2004, 42, 299-306. [CrossRef]

22. Picard-Meyer, E.; De Garam, C.P.; Schereffer, J.L.; Robardet, E.; Cliquet, F. Evaluation of six TaqMan RT-rtPCR kits on two thermocyclers for the reliable detection of rabies virus RNA. J. Veter-Diagn. Investig. 2018, 31, 47-57. [CrossRef]

23. Wakeley, P.R.; Johnson, N.; McElhinney, L.M.; Marston, D.; Sawyer, J.; Fooks, A.R. Development of a real-time, TaqMan reverse transcription-PCR assay for detection and differentiation of lyssavirus genotypes 1, 5, and 6. J. Clin. Microbiol. 2005, 43, $2786-2792$. [CrossRef] [PubMed]

24. Hayman, D.; Banyard, A.C.; Wakeley, P.R.; Harkess, G.; Marston, D.; Wood, J.L.; Cunningham, A.A.; Fooks, A.R. A universal real-time assay for the detection of Lyssaviruses. J. Virol. Methods 2011, 177, 87-93. [CrossRef]

25. Wadhwa, A.; Wilkins, K.; Gao, J.; Condori, R.E.C.; Gigante, C.M.; Zhao, H.; Ma, X.; Ellison, J.A.; Greenberg, L.; Velasco-Villa, A.; et al. A pan-lyssavirus taqman real-time RT-PCR assay for the detection of highly variable rabies virus and other lyssaviruses. PLoS Negl. Trop. Dis. 2017, 11, e0005258. [CrossRef] [PubMed]

26. Gigante, C.M.; Dettinger, L.; Powell, J.W.; Seiders, M.; Condori, R.E.C.; Griesser, R.; Okogi, K.; Carlos, M.; Pesko, K.; Breckenridge, M.; et al. Multi-site evaluation of the LN34 pan-lyssavirus real-time RT-PCR assay for post-mortem rabies diagnostics. PLoS ONE 2018, 13, e0197074. [CrossRef] [PubMed]

27. World Health Organization. Laboratory Techniques in Rabies, 5th ed.; Rupprecht, C.E., Fooks, A.R., Abela-Ridder, B., Eds.; World Health Organization: Geneva, Switzerland, 2019; Volume 2.

28. Orciari, L.A.; Niezgoda, M.; Hanlon, C.A.; Shaddock, J.H.; Sanderlin, D.W.; Yager, P.A.; Rupprecht, C.E. Rapid clearance of SAG-2 rabies virus from dogs after oral vaccination. Vaccine 2001, 19, 4511-4518. [CrossRef]

29. Sievers, F.; Higgins, D.G. Clustal Omega, accurate alignment of very large numbers of sequences. In Multiple Sequence Alignment Methods; Springer: Berlin, Germany, 2013; Volume 1079, pp. 105-116.

30. Ronquist, F.; Teslenko, M.; Van Der Mark, P.; Ayres, D.L.; Darling, A.; Höhna, S.; Larget, B.; Liu, L.; Suchard, M.A.; Huelsenbeck, J.P. MrBayes 3.2: Efficient Bayesian phylogenetic inference and model choice across a large model space. Syst. Biol. 2012, 61, 539-542. [CrossRef] [PubMed]

31. Miller, M.A.; Pfeiffer, W.; Schwartz, T. Creating the CIPRES science gateway for inference of large phylogenetic trees. In Proceedings of the 2010 Gateway Computing Environments Workshop (GCE), New Orleans, LA, USA, 14 November 2010; pp. 1-8. [CrossRef]

32. Nylander, J. Mr Modeltest 2.2. Program Distributed by the Author. Uppsala Evolutionary Biology Centre, Uppsala University. Available online: https:/ / github.com/nylander/MrModeltest2 (accessed on 18 November 2020).

33. Letunic, I.; Bork, P. Interactive tree of life (iTOL) v3: An online tool for the display and annotation of phylogenetic and other trees. Nucleic Acids Res. 2016, 44, W242-W245. [CrossRef]

34. Rambaut, A. Fig Tree v. 1.4.4. 2018. Available online: http://tree.bio.ed.ac.uk/software/figtree/ (accessed on 2 December 2011).

35. LN34 Pan-Lyssavirus Real-Time RT-PCR for Post-Mortem Diagnosis Of rabies in Animals. Available online: https://www. protocols.io/view/ln34-pan-lyssavirus-real-time-rt-pcr-for-post-mort-n4tdgwn. (accessed on 18 November 2020).

36. Smith, J.S. Rabies virus. In Manual of Clinical Microbiology; Ballows, A., Baron, E.S., Pfaller, M.A., Tenover, F.C., Yolken, R.H., Murray, P.R., Eds.; American Society for Microbiology Press: Washington, WA, USA, 1995; pp. 997-1003.

37. Süss, B.; Flekna, G.; Wagner, M.; Hein, I. Studying the effect of single mismatches in primer and probe binding regions on amplification curves and quantification in real-time PCR. J. Microbiol. Methods 2009, 76, 316-319. [CrossRef]

38. Klungthong, C.; Chinnawirotpisan, P.; Hussem, K.; Phonpakobsin, T.; Manasatienkij, W.; Ajariyakhajorn, C.; Rungrojcharoenkit, K.; Gibbons, R.V.; Jarman, R.G. The impact of primer and probe-template mismatches on the sensitivity of pandemic influenza A/H1N1/2009 virus detection by real-time RT-PCR. J. Clin. Virol. 2010, 48, 91-95. [CrossRef]

39. Condori, R.; Niezgoda, M.; Lopez, G.; Matos, C.A.; Mateo, E.D.; Gigante, C.; Hartloge, C.; Filpo, A.P.; Haim, J.; Satheshkumar, P.S.; et al. Using the LN34 pan-lyssavirus real-time RT-PCR assay for rabies diagnosis and rapid genetic typing from formalin-fixed human brain tissue. Viruses 2020, 12, 120. [CrossRef] 